\title{
Upravljanje digitalnom transformacijom državnog poduzeća
}

\section{Digital Transformation Management of a State-owned Enterprise}

\section{Sažetak}

U jeku globalne zdravstvene krize prouzročene pandemijom bolesti COVID-19, nužno je pronaći strateška rješenja za poduzeća. Jedno od takvih operacionalnih izazova je svakako digitalizacija poslovanja. Uspjehe provođenja i upravljanja digitalno transformacijom ovisi o menadžmentu i odlučnosti provedbe iste. Kada je riječ o državni poduzećima, svjesni smo situacije u Republici Hrvatskoj gdje sve više državnih poduzeća u svom djelokrugu posla podliježe novim trendovima. Rijetki su oni koji time čine i iskorak van standardnog core poslovanja i time svojem poduzeću daju dodatnu konkurentsku prednost, a jedno od tih poduzeća je svakako Hrvatska pošta d.d. Sa stanovišta korporacijskog rasta, osobito je važna ona praksa koja je usko povezana sa investiranjem u inovacije, tako da procedure, postupci i pravila kojih se menedžment drži pri praktičnom odlučivanju o investiranju u inovacije postaju značajni izvori temeljem kojih se može proširiti znanje o korporacijskom rastu. Istraživanje ovih specifičnosti, kompletirat će sliku o faktorima, uvjetima i okolnostima koje djeluju u realizaciji korporacijskog rasta hrvatskog državnog poduzeća.

Ključne riječi: teorije rasta i razvoja poduzeća, inovacije, digitalna transformacija

JEL klasifikacija: 032

\section{Abstract}

In the midst of the global health crisis caused by the COVID-19 pandemic, it is necessary to find strategic solutions for enterprises. One of such operational challenges is certainly the digitalization of business. The success of the implementation and management of digital transformation depends on the management and determination to implement it. When it comes to state-owned enterprises, we are aware of the situation in the Republic of Croatia where more and more state-owned enterprises are subject to new trends in their scope of work. Those who make a step beyond the standard core business and thus give their enterprise an additional competitive advantage are rare, and one of these enterprises is certainly Hrvatska pošta d.d. From the point of view of corporate growth, the practice that is closely related to investing in innovation is especially important, so that the procedures, processes and rules that management follows when making practical decisions about investing in innovation become important sources for expanding knowledge about corporate growth. The research of these specifics will complete the picture of the factors, conditions and circumstances that operate in the realization of the corporate growth of the Croatian state-owned enterprise.

Keywords: enterprise growth and development theories, innovation, digital transformation JEL classification: 032

\section{Martina Sopta}

Izv. prof. dr. sc.

Ekonomski fakultet Sveucilišta u Zagrebu

E-mail: msopta@efzg.hr

\section{Martina Sopta}

Assoc. prof.

Faculty of Economics and Business,

University of Zagreb

E-mail:msopta@efzg.hr 
Sopta, M.

Upravljanje digitalnom transformacijom državnog poduzeća

\section{Teorije rasta i razvoja poduzeća}

\subsection{Teorije rasta poduzeća}

Poduzeća su nastala ponajprije zbog mogućnosti realizacije složenih i kompleksnih pothvata te dijeljenja rizika. Njihovo je postojanje i djelovanje, slabijim pa sve snažnijim intenzitetom remetilo mir deduktivne ekonomske znanosti sve do druge polovine XX stoljeća kada su se teorije poduzeća počele diferencirati nastojeći dublje objasniti zašto poduzeća uopće postoje, koje su odrednice i mehanizmi funkcioniranja poduzeća, te koje su determinante i granice rasta poduzeća, a sve to na podlozi postojanja kompleksne i nepredvidljive okoline.

Prvi pokušaj sustavnog razmatranja i razumijevanja korporacijskog rasta vezan je uz E. Penrose koja je ne samo podastrla i elaborirala determinirajuće faktore korporacijskog rasta, nego je, isto tako, i upitala se gdje su granice rasta poduzeća (Santini, 2011.). Tako dubok i tako obuhvatan rad podstakao je snažnu znanstvenu aktivnost unutar koje je posebno zanimljiv onaj pravac koji modelira korporacijski rast. Miller-Modglianijeva teorija rasta naglašava kako je rast vrijednosti korporacije determiniran investicijskom politikom odnosno snagom zarađivanja korporacijske imovine i snažno je prihvaćena od strane znanstvenika upravljačkih financija dioničkih društava. Na tragu ortodoksne mikroekonomske teorije iznimno je važna teorija rasta artikulirana od strane R.L. Marrisa, autora znamenite sintagme menedžerski kapitalizam. Njegov je model rasta utemeljen na dvije poluge $i$ to: ponudi kapitala, $s$ jedne, te potražnji za kapitalom, s druge strane. Upravo ovaj model podstakao je mnoštvo istraživanja u pravcu artikulacije i implementacije mehanizama interne alokacije kapitala (Santini, 2001.).

Korporacijsko praktično ponašanje, međutim, neovisno o tome što su korporacijskom poslovanju znanstvenici mislili i pisali, išlo je svojim tijekom o čemu postoje brojna svjedočanstva onih znanosti, koje su sui generis nastale, kao što su ekonomika poduzeća, znanstvena organizacija rada, računovodstvo itd.. Sa stanovišta korporacijskog rasta, osobito je važna ona praksa koja je usko povezana sa investiranjem, tako da procedure, postupci i pravila kojih se menedžment drži pri praktičnom odlučivanju o investiranju postaju značajni izvori temeljem kojih se može proširiti znanje o korporacijskom rastu. Utemeljeno je očekivanje, ponajprije zbog različitih performansi okoline, da se pri investiranju američka poduzeća i ona japanska jednako ne ponašaju, ali je isto tako utemeljeno očekivanje da i investicijsko ponašanje njemačkih dioničkih društava najvjerojatnije divergira od ponašanje svojih američkih pandana. Istraživanje ovih specifičnosti, čini se, kompletirat će sliku o faktorima, uvjetima i okolnostima koje djeluju u realizaciji korporacijskog rasta.

\subsubsection{Ciljevi rasta poduzeća}

Kao što je već rečeno u prvom poglavlju rada gdje su objašnjeni ciljevi poduzeća možemo kazati da su, naime, važni ne samo parametri kao što su troškovi i potražnja, nego i ciljna funkcija ponašanja koja se, u tradicionalnom duhu, ogleda u ostvarivanju profita.U bilo kojem vremenu, poduzeće će nastojati ostvariti jedan ili više ciljeva u odnosu na dana joj ograničenja. Znači, u kvantitativnom smislu se odnosi rast poduzeća. U svojem djelovanju, prema neoklasičnom gledištu, poduzeće se sučeljava se danim troškovnim uvjetima, napose ima vlastitu funkciju graničnih troškova, $s$ jedne strane, te položajem i nagibom krivulje potražnje iz koje se generira funkcija graničnog prihoda, s druge strane, da bi odlukom, utemeljenom na graničnom načelu, o količini vlastite proizvodnje nastojalo ostvariti maksimalnu razinu profita. Očigledno je, odatle, da poduzeće pasivno prihvaća ne samo uvjete poslovanja, nego i konsekvence ove i ovakve situacije koje mogu uključivati stabilni ili opadajući profit, ali i odlazak iz industrije u kojoj postoji i u kojoj djeluje.

\subsubsection{Rast dobiti}

Temeljna premisa neoklasičnog pogleda na poduzeće ogleda se u tvrdnji da je cilj ponašanja poduzeća maksimaliziranje profita. Kroz proizvodnju dobara ili pružanje usluga, drugim riječima, poduzeće zadovoljava platežno sposobne potrebe i ništa drugo ne želi do li maksimalizirati profit. Neoklasična je tvrtka na taj način orijentirana na maksimiziranje profita odnosno minimaliziranje troškova budući da prodaje po zatečenim cijenama na koje ne može utjecati. 
Proizvodnja neoklasične tvrtke opisuje se proizvodnom funkcijom koja pokazuje odnos između proizvoda i proizvodnih faktora. Troškovi se izvode iz proizvodne funkcije sve dotle dok su cijene proizvodnih faktore na tržištu proizvodnih faktora poznate. Prihodi neoklasičnog poduzeća izvode se iz skale tržište potražnje koja pokazuje broj proizvoda koje kupci žele kupiti pri različitim cijenama za jedinicu proizvoda jednostavnom multiplikacijom količine proizvoda i cijene. Budući da je cijena konstantna, jedina determinanta prihoda je količina proizvoda, a također i visine troškova. Diferencija prihoda i troškova predstavlja profit i plauzabilno je da poduzeće nastoji utvrditi onu količinu proizvoda kod koje maksimalizira razliku prihoda i troškova, tj. vlastiti profit. Poduzeće će, drugim riječima, povećavati vlastitu proizvodnju tako dugo dok se marginalni prihodi ne izjednače s marginalnim troškovima. Kad se postigne njihova jednakost, poduzeće maksimalizira vlastiti profit.

\subsubsection{Rast obujma proizvodnje}

Nasuprot tome, aktivno ponašanje poduzeća uključuje njezino nastojanje tijekom vremena da se modificiraju ili pak, da se pomaknu egzogeno joj nametnuta ograničenja troškovno-potražne situacije, da se zadržimo na neoklasičnom gledištu, kako bi se djelotvornije ostvarili postavljeni ciljevi. Oglašavanje, istraživanje i razvoj, diverzifikacija proizvoda, sporazumijevanje, integriranje, preuzimanje itd. označavaju oblike kojima poduzeće može promijeniti navedena ograničenja. Kako se sve ove utjecajne varijable odnose na velika i snažna poduzeća, koje tradicionalni pristup ignorira, postaje razvidno da je koncept po kojem su ekonomski entiteti aktivni, tj. da mogu mijenjati egzogeno dana ograničenja, daleko vjerodostojniji i djelotvorniji. Povećana se djelotvornost kondenzira u sintagmi diskrecionog ponašanja, a ono je, nota bene, u izravnoj suprotnosti pasivnom ponašanju koje inače adoptira neoklasična mikroekonomska paradigma.

\subsubsection{Izvedeni ciljevi rasta}

Ekonomija razmjera bi mogla biti jedan od ciljeva rasta korporacije, što je već i navedeno u drugom poglavlju rada. Tada bi trebalo promatrati korporacijskog ponašanja glede troškova ${ }^{1}$, što bi zbog ograničena prostora bilo nerazumno, već se može zaključiti kako diskreciono ponašanje poduzeća rezultira činjenicom da društvo, manipulirajući varijablama odlučivanja, može ostvarivati profite neovisno od općeg razvoja industrije što je po tradicionalnom pristupu nezamislivo.

\subsubsection{Putovi rasta poduzeća}

\subsubsection{Vanjski put rasta}

Mada je distinkcija između pasivnog i aktivnog ponašanja poduzeća prijeko potrebna, u najmanju ruku da se sagleda razlika u broju i vrsti relevantnih parametara odlučivanja, ona nipošto ne sugerira da su oni supstituti. Upravo obratno, pasivno i aktivno ponašanje mora se promatrati i smatrati komplementarnim kako bi se putovi rasta poduzeća bilo vanjski ili unutarnji mogli međusobno isprepletati. Tradicionalni se pristup, kako je ranije naglašeno, fokusira na potražnju, $s$ jedne, i troškove, $s$ druge strane, te se, odatle, operira unutar dvodimenzionalnog prostora odlučivanja. Moderni pristup uvažava tradicionalne temelje odlučivanja, ali ih proširuje vlastitim aktivnim djelovanjem. On, naime, potražnju uvažava kao egzogenu varijablu, ali je također "prerađuje" na način da istodobno bude instrumentalna varijabla osobito putem diskrecijskih odluka glede oglašavanja, diferenciranja, itd. Ovo uznemiravanje potražnje, mada se dojmljuje pukim proširenjem, u sebi ipak skriva supstancijalni značaj koji se ponajprije ogleda u činjenici da korporacijska diskrecija u odlučivanju mijenja svoju izvanjskost, okolinu, industriju, napose industrijsku potražnju mijenjajuće joj nagib i/ili položaj.

1 Uzmimo primjer ekonomije razmjera. U duhu tradicionalnog pristupa mikroekonomske teorije, ekonomija se razmjera realizira silaženjem niz krivulju dugoročnih prosječnih ukupnih troškova, ali kad se dosegne kritična količina proizvodnje u industriji, tada stanje industrije nije više okolina korporacije kojoj se mora prilagoditi, već je upravo industrija ta koja se mijenja glede efikasnosti i cijena, glede koncentracije, itd. Jednostavno govoreći, korporacija ima svoju gravitacijsku snagu kojom utječe na svoju okolinu. Izrađene su brojne studije u kojima se analiza ekonomija razmjera, odnos profitabilnosti i veličine korporacije, industrijska koncentracija, rast, itd. Vidjeti: Yamey, B. S. (ur.) (1973) Economics of Industrial Structure: Selected Readings. Harmondsworth, Middlesex, England: Penguin Books, Ltd., 233-262. 
Sopta, M.

Upravljanje digitalnom transformacijom državnog poduzeća
Ako diskrecionom ponašanju pristupe i drugog poduzeća u industriji, a to je conditio sine qua non njihove opstojnosti, tada se stvari usložnjavaju i industrijska potražnje, da se vratimo ilustrativnom primjeru, više nije egzogena varijabla u smislu tradicionalne teorije, već je prividno egzogena varijabla snažno prožeta interaktivnim djelovanjem poduzeća $u$ industriji. $U$ tim i takvim uvjetima, teško je jasno i nedvojbeno razlikovati što je uzrok, a što je posljedica promjene industrijske potražnje, kako je to bilo moguće u tradicionalnom pristupu. Moderni pristup, nasuprot tradicionalnom, imanentnim koncepcijama i razvijenim alatima, $s$ tim se neodređenostima može nositi, te može snažno pridonijeti razlikovanju onih faktora, uvjeta i okolnosti koji su posljedicom interaktivnog diskrecionog ponašanja korporacija odnosno dioničkih društava u industriji 2 .

\subsubsection{Unutarnji put rasta}

Korporacijski menedžment, tzv. vršni menedžment, mada je pojavno gledajući zadužen i odgovoran za korporacijski rast, on ipak podliježe stanju kojeg H. Simon (Santini, 2001.) atribuira sintagmom ograničena racionalnost. Kako bi vlastite nesavršenosti smanjio, ali ne i anulirao, vršni se menedžment mora osloniti na odgovarajuće mehanizme pomoću kojih biva u stanju koordinirati djelovanje povećeg broja intrakorporacijskih sklopova (organizacijski teoretičari zovu ih poslovne jedinice, upravljački orijentirani računovođe centri odgovornosti, itd.) na čelu kojih se nalaze menedžeri ograničenih ovlasti, tzv. menedžment srednjih razina. Jedan takav mehanizam svakako je interno tržište kapitala, institucija koja omogućava i olakšava internu alokaciju kapitala, odnosno conditio sine qua non korporacijskog rasta. Važno je znati, otuda, ne samo koja pravila i procedure usustaviti na internom tržištu kapitala, nego i koje alate koristiti pri izboru opcija koje akteri internog tržišta kapitala kandidiraju u nakani osiguranja korporacijskog rasta, a sve to na podlozi prijeke potrebe ubrzanja odlučivanja.

Oslanjajući se na Coase-ov znameniti članak ${ }^{3}$, u kojem je dobitnik Nobelove nagrade za ekonomiju 1991. godine postavio temeljno pitanje: zašto poduzeća uopće egzistiraju?, može se elaborirati važnost postojanja internog tržišta kapitala. Prema Coase-ovom gledištu, kojeg je zdušno akceptirao 0 . E. Williamson, najvjerniji i najveći zagovornik Coaseovog učenja i utemeljitelj teorije transakcijskih troškova, poduzeća postoje onda, utemeljuju se, kad je neku transakciju učinkovitije organizirati unutar poduzeća, pod nadzorom njezinog vlasnika ili hijerarhije, nego putem uporabe cjenovnog mehanizma odnosno tržišta shvaćenog u duhu neoklasične ekonomske paradigme.

Jednom kad se odluči koje će se sve transakcije realizirati unutar poduzeća odnosno u ovom slučaju poduzeća, a koje će se realizirati preko tržišta, istodobno je postavljena i granica između firme, njezine unutrašnjosti, i njezine okoline odnosno njezine izvanjskosti. Mada konkretne granice poduzeća nije lagano odrediti ${ }^{4}$, intuitivno je ipak jasno da one moraju negdje postojati. Razlučivanjem izvanjskosti, okruženja, tržišta, od unutrašnjosti, de facto se razdvajaju dva režima realizacije ekonomske djelatnosti. Izvan dioničkih društava i dalje djeluje tržišni sustav sa imanentnim

2 Industrijska krivulja potražnje determinirana je izravno i neizravno veličinom korporacija, njezinim odlukama o investiranju u kapacitete, tržište, istraživanje i razvoj, stupnjem industrijske koncentracije, diverzifikacijom itd.. Svi ovi faktori, uvjeti i okolnosti, u tradicionalnom pristupu potražnji uopće se ne spominju koji se drži premise o nedodirljivosti suvereniteta potrošača. Šire o tome u: Kuenne, R. E. (1966) Monopolistic Competition Theory: Studies in Impact. Essays in Honour of E.H. Chamberlin. Wiley; Kamerschen, D. R. (1969) Readings in Microeconomics. Wiley; Mansfield, E. (1993) Managerial Economics: Theory, Applications, and Cases. New York: Norton.

3 Vidi: Coase, R.(1937) The Nature of the Firm. Economica, 4: 386-405. Ovaj članak je pretiskan u 0.E. Williamson, S.E. Winter (ur.) (1993) The Nature of the Firm. Origins, Evolution, and Development. New York: Oxford University Press, 2: 18-33. Inače, u ovoj knjizi prikazan je Coase-ov utjecaj na ekonomsku teoriju, napose teorije firme, a također je pretiskan i Coase-ov govor prilikom dobivanja Nobelove nagrade.

4 Objašnjenje teškoća utvrđivanja granica poduzeća može se naći u Cheung, S. N. S. (1983) The Contractual Nature of the Firm Journal of Law and Economics, XXVI (1): 1-21, pretiskano u Langois, R. N., Fu-Lai Yu, T., Robertson, P. (2002) Alternative Theories of the Firm.Edward Elgar Publishing Limited, Cheltenham, Glos GL 50 i UA, UK, 245-265. 
cjenovnim mehanizmom, a unutar poduzeća, u prvi plan izbija hijerarhija koja, u pravilu, adoptira pozitivne odrednice tržišnog sustava djelovanja.

Kako bi se ostvario temeljni cilj poslovanja maksimiziranje neto-vrijednosti - jasno je da hijerarhija mora imati neki medij preko kojeg će, uz ostalo, realizirati alokaciju kapitala. I upravo u internom tržištu kapitala, hijerarhija unutar poduzeća nastoji sprovoditi alokaciju kapitala rukovodeći se načelom učinkovitosti, tj. kreativno sintetizirati pozitivne strane administrativnog i tržišnog režima djelovanja. Kad poduzeće, nasuprot tome, ne bi učinkovitost iz prednosti dvaju sustava djelovanja mogle ostvariti, tada ne bi postojao raison d'etre da se ekonomska transakcija odvija unutar poduzeća. Mada se ta i takva transakcija i dalje može realizirati unutar poduzeća, sa ekonomskog je gledišta to neracionalno. Kad bi se ove i ovakve neracionalnosti gomilale unutar neke partikularne poduzeća, prije ili kasnije, nestao bi raison d'etre postojanja poduzeća u cjelini ${ }^{5}$.

\subsection{Teorije razvoja poduzeća}

Osnovano je misliti da teorije razvoja poduzeća mogu se konceptualno prikazati kroz dva teoretska područja: interno tržište kapitala i slobodni novčani tok. Nastanak i egzistencija dioničkih društava koja mnoštvo transakcija obavljaju unutar sebe pod komandom hijerarhije i koja istodobno na eksternom tržištu ispoljavaju tržišnu snagu, plijenila je pažnju ekonomskih znanstvenika 0 čemu postoji opsežna literatura 6 . Postignuća ove literature nisu se mogla ignorirati ni od strane ortodoksnih sljedbenika neoklasične ekonomske teorije između kojih osobito treba spomenuti dobitnike Nobelove nagrade G. Stiglera i K. Arrowa. Uz neoklasičnu ekonomsku teoriju, otada, uz bok stoji nova institucionalna ekonomija/ekonomika (zanimljivo je da je R. Coase tek 1992. godine dobio Nobelovu nagradu za ekonomiju iako je još 1937. godine postavio fundamentalno pitanje: zašto poduzeća uopće postoje?) i postalo je neizbježno izučavati što to, i kako, hijerarhija unutar velikih i snažnih poduzeća čini, jer to što čini ima snažan utjecaj na ono izvan velikih i snažnih dioničkih društava, a to je tradicionalno neoklasično tržište. Interna ekonomija, na taj način, prožimlje eksternu (tržišnu) ekonomiju i prožeta je njome. Statističke su procjene, da se više realnih transakcija odvija interno, dakle pod komandom hijerarhija dioničkih društava, nego što se odvija putem tradicionalnog neoklasičnog tržišta. Polazeći od hijerarhije, drugim riječima, upitali smo se: što joj treba kako bi učinkovito vodila kompleks interne ekonomije na podlozi permanentne promjenjivosti i nepredvidljivosti?

Jasno je da hijerarhiji treba mnogo toga, ali svesti kompleksni problem interne ekonomije na shemu mehanizmi koordinacije (interno tržište kapitala i interno tržište proizvoda-transferne cijene), s jedne strane, te na alate vođenja (menadžersko stimuliranje i menadžerski informacijski sustav), s druge strane, učinilo je ovaj pristup fenomenološki.

Niti jedna hijerarhija, drugim riječima, zato što je racionalno ograničena $(H$. Simon, također nobelovac), objektivno ne može voditi kompleks interne ekonomije ukoliko istodobno ne raspolaže adekvatnim konceptima, modelima, metodama i sl. parcijalnog obuhvata koje će kasnije kreativno sintetizirati u jedinstvenu cjelinu. Mada se u literaturi spominje i ranije, tek s 0. E. Williamsonom (Markets and Hierarchies, 1975.) interno tržište kapitala privlači veću pozornost i danas je općepoznato i općeprihvaćeno kao hipoteza internog tržišta kapitala. Nasuprot ovoj hipotezi, stoji M. Jensen ("Agency costs of free cash flow, corporate finance, and tekeovers", AER, 76, 1986.), inače sljedbenik ortodoksne linije upravljačkih (korporativnih) financija, i njegova općepoznata hipoteza slobodnog novčanog toka. Dok hipoteza internog tržišta kapitala tvrdi da hijerarhija može povećavati vrijednost korporacije (dakle ona se

5 Iskustvno pokazuje da su korporacije koje dozvoljavaju gomilanje neracionalnosti lak plijen preuzimanja i predmet sanacije poduzet od preuzimatelja, razumije se, tek nakon što otpusti nesposoban menedžment.

6 Vidi Marris, R., Wood, A. (1971) The Corporate Economy: growth, competition, and innovative potential. Springer; Marris, R. (1972) Is Corporate Economy A Corporate State, AER, 62(1/2): 103-115; Spence, A. M. (1975) The Economics of Internal Organization: An Intruduction. The Bell Journal of Economics, 6(1):163-172; Williamson, 0. E.(1975) Markets and Hierarchie. New York, 2630: The Free Press; itd. 
Sopta, M.

Upravljanje digitalnom transformacijom državnog poduzeća neće nelojalno ponašati), dotle hipoteza slobodnog novčanog toka tvrdi da slobodni novčani tok treba 'maknuti' od hijerarhije (dakle ona će se nelojalno ponašati) $i$ isplatiti ga dioničarima u obliku dividendi. Odnosno slobodni novčani tok predstavlja višak novčanog toka koji je preostao nakon što se isfinanciraju svi planirani projekti i tim novcem mogu se otkupljivati poduzeća uz uporabu poluge.

Vrijednost poslovnih jedinica definira se putem slobodnog novčanog toka koji one generiraju obavljajući svoju primarnu djelatnost?. Slobodni novčani tokovi generirani kroz planirani vremenski horizont promatranja predstavljaju sadašnju vrijednosti budućih slobodnih novčanih tokova. Generirani diskontirani slobodni novčani tokovi nazivaju se slobodnima jer obuhvaćaju isključivo raspoloživa novčana sredstva iz primarnog poslovanja poduzeća. U teoriji i praksi ${ }^{8}$ postoje više alternativnih modela vrednovanja slobodnih novčanih tokova poduzeća $s$ pripadajućim modelima procjenjivanja diskontne stope među kojima se ističu sljedeća dva: model diskontiranih novčanih tokova i model ekonomskog profita.

Postoje i drugi alternativni modeli vrednovanja poduzeća temeljeni na koncepciji diskontiranih novčanih tokova poduzeća ${ }^{9}$ koji pokazuju slične ili gotovo iste rezultate vrednovanja kao i prethodna dva modela. Međutim, njihova praktična primjena je ograničena.

\subsection{Inovacije}

\subsubsection{Inovacijski projekti kao rast tržišta}

U duhu mikroekonomske teorije, na inovacije ${ }^{10}$ će se promatrati kroz tri smjera važna za poduzeća i to kao rast tržišta, rast proizvodnje i rast procesa. Ako se pogleda povijest najvećeg dijela današnjih velikih dioničkih društava u SAD-u primjerice, lako je zapaziti činjenicu da se njihov rast najvećim dijelom može objasniti neprestanim postojanjem povoljnih prilika za investiranje (inovacije) koje su se financirale iz ranije ostvarenih, ali neisplaćenih profita (interno financiranje) ${ }^{11}$. U protivnom, ukoliko korporacija nema profitabilnih investicijskih opcija, nema dvojbe o tome da bi koeficijent zadržanog profita trebao iznositi bliže nuli što znači da će se tek zanemarivi dio profita nakon oporezivanja ostaviti unutar korporacije, zbog traganja za profitabilnim investicijskim opcijama primjerice, a najveći će se dio isplatiti dioničarima u obliku dividendi. U slučaju rasta investicijskih projekata poduzeća, menadžment će se odlučiti za interno financiranje koje se ostvaruje na štetu dioničara koji će in ultima linea biti obilato financijski kompenzirani.

Jednom kad se poznaje vrelište investicijskih projekata, nalazimo se pred zadatkom njihove sistematizacije sukladno određenim atributima. Iz prethodnih je izlaganja sasvim jasno da su relevantna dva atributa i to: očekivana stopa povrata, $s$ jedne strane, te visina kapitala potrebnog za individualni investicijski projekt, s druge strane. Kvantifikacija očekivane stope povrata nije predmet ovog poglavlja ${ }^{12}$, ali je iz prethodnih izlaganja jasno da se ona treba temeljiti na proizvodnosti kapitala

7 Ovdje se misli na redovnu odnosno operativnu aktivnost poduzeća.

8 Više o tome vidjeti Copeland, T.,Koller, T., Murrin,J.(1995) Valuation: Measuring and Managing the Value of Companies. New York: McKinsey \& Company, Inc.

9 Više o tome vidjeti Copeland, T.,Koller, T.,Murrin,J.(1995) Valuation:Measuring and Managing the Value of Companies.New York: McKinsey \& Company, Inc.

10 Mikroekonomska obrada inovacije, shvaćene kao tržišno efektuirane invencije,u prikladnoj se formi može naći u: Mansfield, E. (1988) Microeconomics. Theory and Applications. New York: W.W. Norton \& Company.

11 Tu je činjenicu, po našem sudu, najbolje dokumentirao W. Lazonick. Vidi: Lazonick, W. (1992) Controlling the Market forCorporate Control. The Historical Significance of Managerial Capitalism. Industrial and Corporate Change, 1(3),445-488.

120 tome postoji brojna literatura. Između drugih, vidjeti: Orsag S. (2002) Budžetiranja kapitala: Procjena investicijskih projekata.Zagreb: Masmedia. 
iz koje se pak, izvodi visina profita koji se očekuje ostvariti kroz određeni broj godina u budućnosti. Svota kapitala potrebnog za individualni projekt proizlazi iz same analize proizvodnosti kapitala unutar koje se nalaze normativi fiksnih faktora (prisjetimo se zemljišta, ali možemo dodati proizvodnu opremu i sl.) koje će biti potrebno angažirati za realizaciju ekonomskog cilja tog projekta. Prije nego što se pristupi analizi rasta inovacija za što kao posljedicu ima rast proizvodnje, potrebno je zaključiti da je neupitna važnost razvoja investicijskih projekata unutar poduzeća kako bi ono za rezultat imalo jačanje tog istog društva na tržištu u odnosu na konkurenciju.

\subsubsection{Inovacije kao rast proizvodnje}

Zamišljena krivulja investicijskih mogućnosti poduzeća pokazuje načine i puteve na koji poduzeće alocira financijski kapital na pojedine skupine investicijskih projekata unutar kojih se odvijaju proizvodno-ekonomski procesi što za posljedicu imaju rast proizvodnje poduzeća. Nema nikakve dvojbe o tome da će poduzeće ponajprije željeti realizirati one investicijske projekte koji rezultiraju najvišom očekivanom stopom povrata, a zatim će uslijediti alokacija financijskog kapitala na ostale investicijske projekte koji rezultiraju sve nižim i nižim očekivanim stopama povrata. Krivulja investicijskih mogućnosti poduzeća, prema tome, uz logiku izbora investicijskih projekata, istodobno odražava i posljedice tog izbora, a one se očituju u opadajućoj učinkovitosti upotrebe financijskog kapitala.

Zbog svih tih informacija, na krivulju investicijskih mogućnosti korporacije treba gledati kao na iznimno važnu podlogu menadžerskog odlučivanju 0 alokaciji financijskog kapitala unutar korporacija koje se sastoje od pozamašnog broja vlastitih poslovnih jedinica zbog čega se javlja potreba poduzeća da ustoliči instituciju već spomenutog internog tržišta kapitala.

\subsubsection{Inovacije kao rast procesa}

Promatrajući dosadašnju analizu inovacija, može se reći da je hipotetski postavljeno poduzeće upotrebljavajući financijski kapital, ostvarilo toliku visinu očekivane stope povrata koju u budućnosti, sukladno načelu opadajuće učinkovitosti upotrebe financijskog kapitala, više uopće ne može ostvariti.
Ako je to tako, tada se pitamo: da li inovacije rezultiraju nižim očekivanim stopama povrata od onih koje su se u prošlosti, dakle prije aktualnih inovacija, ostvarivale? Odgovor je najvjerojatnije negativan. Ako se, drugim riječima, radi 0 iznimnim inovacijama, tada bi trebalo očekivati da će poduzeće, temeljem tih iznimnim inovacija, ostvariti veće očekivane stope povrata od onih koje je ostvarivala u prošlosti. Dakle, osim rasta tržišta i proizvodnje,slijedeća kategorija kojom bi dioničkog društvo kroz alate inovacijskih projekata ostvarilo jest rast procesa. Rast procesa bi za posljedicu imalo povećanje i proizvodnje i na kraju rast udjela na tržištu čime se može zaključiti da su inovacije bitne za svaki segment poslovanja poduzeća.

\section{Optimalna organizacijska struktura Hrvatske pošte d.d.}

\subsection{Uloga menadžmenta}

Optimalna organizacijska struktura promatranog državnog poduzeća determinirana je menadžmentom. Provodeći istraživanje za potrebe ovog rada, proveo se intervju s gosp. Čulom, Predsjednikom uprave Hrvatske pošte koji je i ustupio potrebne podatke za empirijski dio istraživanja. Uloga menadžmenata je efikasno upravljati složeni poslovnim procesima i posebno u uvjetima specifičnosti kriza kao što je COVID-19 kriza. Također je bitan razvoj poduzeća u sklopu digitalne transformacije. Uvođenjem procesa digitalne transformacije, menadžment poduzeća postavlja nove strateške smjernice razvoja poduzeća. Na primjeru Hrvatske pošte d.d. se prikazuje kako su odluke uprave pridonijele razvoju i osnaživanju poduzeća ne samo na hrvatskom tržištu, nego i potencijalnom širenju u regiji što je nužan preduvjet ovakvog tipa poduzeća za daljnjim razvojem.

\subsection{Povezanost vlasničke strukture na otpornost poduzeća u kriznim situacijama}

Uloga menadžmenta u stvaranju optimalne strukture je usko povezana s vlasničkom strukturom. U promatranom poduzeću imamo situaciju gdje je država vlasnik poduzeća jer je Hrvatska pošta d.d. od strateškog interesa za RH. Budućnost će pokazati treba li država biti potpuni vlasnik ili samo većinski, ali ono što je neupitno su usluge koje
Sopta, M.

Upravljanje digitalnom transformacijom državnog poduzeća 
Sopta, M.

Upravljanje digitalnom transformacijom državnog poduzeća se pružaju putem Hrvatske pošte d.d. Svakako je važno istaknuti da nužnost digitalne transformacije proizlazi od strane menadžmenta što ukazuje da državna poduzeća unatoč uobičajenoj slici, prate trendove na poslovnim tržištima. Povezanost vlasničke strukture na otpornost poduzeća u kriznim situacijama se najbolje iskazuje kroz ostvarene poslovne rezultate u trenutnoj COVID-19 krizi gdje se uočava trend dostave non-core usluga Pošte što ukazuje na prilagođavanje menadžmenta nastaloj situaciji i pronalaženju novih mogućnosti zarade za poduzeće u nastaloj kriznoj situaciji. Također je važno ovdje naglasiti uspješnost upravljanja poduzećem odnosno upravljanje ljudskim potencijalima i organizacijski procesima u vrijeme kriznih razdoblja, kao i krizno komuniciranje unutar poduzeća. Sve prethodno navedeno nije predmet istraživanja rada, ali svakako je uključeno u procese kvalitetnog upravljanja poduzećem u vrijeme COVID-19 krize. Ovdje se primjećuje i važnost države da prepusti odlučivanje stručnom menadžmentu u situacijama kada se treba iskazati na poslovnom tržištu $i$ iskoristiti prednosti koje predmetno poduzeće ima da iskristalizira svoje potencijale. Tako je Hrvatskoj pošti promet porastao za $30 \%$ u 2020. godini u odnosu na isto razdoblje lani jer su se na vrijeme povezali s hrvatskim OPG-ovima i plasirali njihove proizvode do krajnjih kupaca. Ovih $30 \%$ se odnosi isključivo na rast volumena paketa. Web trgovina Žuti klik je rasla $300 \%$, a naravno zbog pravovremenog pozicioniranja i uvrštavanja ponude tri godine prije pojavljivanja pandemije.

\subsection{Upravljanje razvojem tehnologije i inovacijskom aktivnošću}

Promatrajući temeljne aktivnosti poslovanja Hrvatske pošte d.d. stječe se dojam da je u zadnjih nekoliko godina postignut veliki pomak prema pružanju novih usluga. Od žutog klika odnosno portala Internet prodaje, do financijskih usluga, e-pošte i postavljanja maloprodajne mreže kao platforme potencijalnog aktivnog nositelja cijelog niza proizvoda i usluga raznih ponuditelja na tržištu. Svojom logističkom mrežom i kanalima sa 47 milijuna prijeđenih kilometara godišnje i preko 2500 vozila unutar dostavne mreže može se zaključiti da je u logističkom smislu Hrvatske pošta među najjačim logistički igračima, ne samo u Hrvatskoj, već i u regiji.

Hrvatska pošta d.d. u 2018. godini ima ostvaren rast prihoda od 3,1 \% u odnosu na 2017. godinu, EBITDA marža od $11,6 \%$ i dobit od 39,4 mil. kn od čega $63,1 \%$ u strukturi prihoda od prodaje proizlazi iz poštanskih usluga, 16,1 \% financijskih usluga, što je veliki iskorak, $11,2 \%$ paketi i ekspres, maloprodaja $4,3 \%$ što bi trebalo biti puno veće s obzirom na broj poslovnica, te digitalne usluge $1,8 \% \mathrm{~s}$ tendencijom rasta i ostale usluge 3,5\%. U 2018. godini na povećanje prihoda i dobiti utjecaj je imala prodaja EVO TV-a od 79,8 mil. kn.

Slika 1. Razvojna strategija Hrvatske pošte d.d.

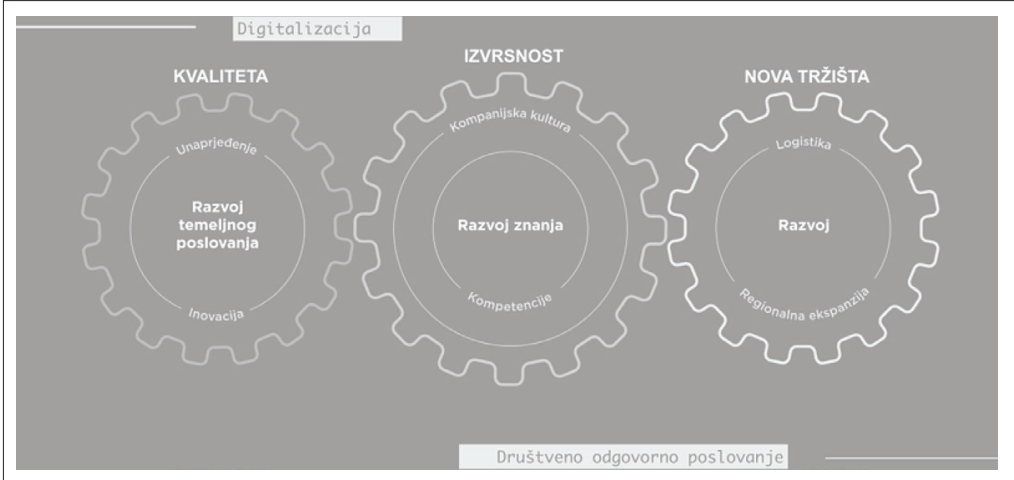

Izvor: Hrvatska pošta d.d. 


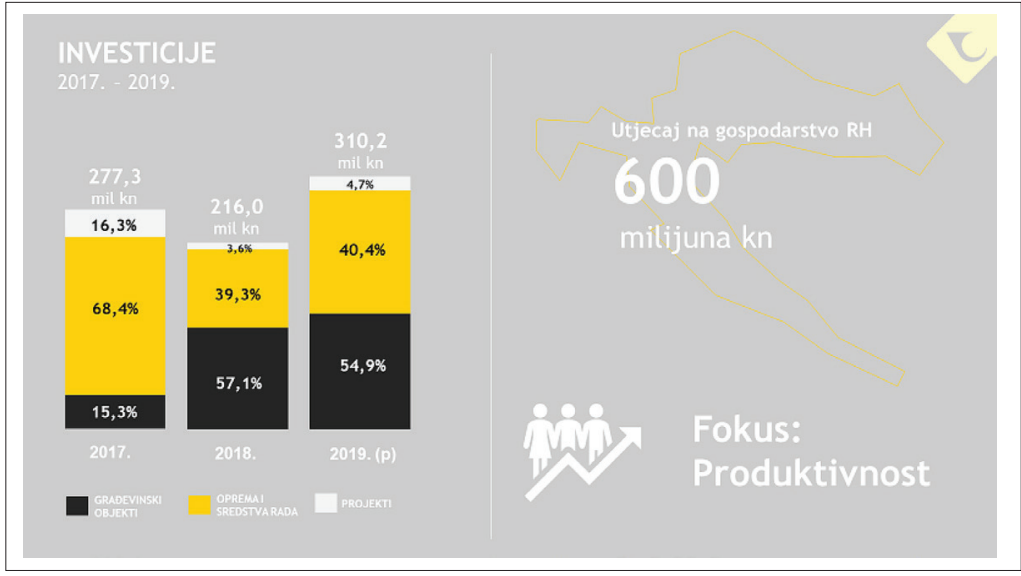

Izvor: Hrvatska pošta d.d.

U 2019. godini se ostvario blagi rast prihoda od 3\% u iznosu 1,78 mlrd. kn i dobit od 121,2 mil. kn ${ }^{13}$ čime se ukazuje na trend rasta što je veliki uspjeh s obzirom da je pošta bila financijski gubitaš. U nekoliko smjerova se strateški razvija Hrvatska pošta d.d. Prije svega razvojem temeljnih aktivnosti što uključuje i širenja na nova tř̌išta. Zatim razvoj znanja i tehnologija kroz adekvatno upravljanjem inovacijskih aktivnosti. Nužnost regionalne ekspanzije i naravno društveno odgovorno poslovanje. Investicije su nužan iskorak u razvoj zacrtane upravljačke strategije. Ključne realizirane investicije ${ }^{14}$ u 2018. godini su izgradnja NOVOG SORTIRNOG CENTRA - 113,9 mil. kn, SASP - nabava paketskog stroja 13,1 mil. kn, daljnja IT ulaganja, projekti kao što su DIGITALNI POŠTAR - 7,8 mil. kn dok su ključne realizirane investicije ${ }^{15}$ u 2019. godini daljnja ulaganja novi sortirni centar - 81,3 mil. kn, ostala ulaganja u građevinske objekte - 71,8 mil. kn, MIPS aplikacije - 6,6 mil. kn, nadogradnja sustava ePošta - 3,1 mil. kn i električna transportna vozila (20 vozila - 1,6 mil. kn).

Sve prethodno navedeno prikazuje napore menadžmenta da se ulaže u razvoj novih tehnologija, a prije svega adekvatne logističke platforme koja bi te nove tehnologije mogla konkretno i pratiti. Upravo je logistika ključna konkurentska prednost promatranog poduzeća i ona je podložna trendovima na svjetskom tržištu kao što su globalizacija, e-trgovina, digitalizacija i održivost.

\section{Zaključak}

Promatrajući polaznu hipotezu rada da su inovacije dobar put razvojne strategije poduzeća posebice u ovakvim krizama, može se, nakon provođenja istraživanja, zaključiti da Hrvatska pošta d.d. strateški promišljeno ulazi u novu eru digitalnog doba koje bi je, uz konkurentske prednosti pošte, trebalo postaviti na tržišne okvire van granice RH. Uprava stavlja fokus na krajnjeg kupca i time podrazumijeva klijentocentrični model koji uključuje prije svega identificiranost s proizvodom, zatim izvrsnost procesa (efikasnost internih procesa u prikupljanju i obradi informacija 0 kupcima: call centri, dedicirane e-mail adrese,

13 Hrvatska pošta d.d. (2019) Godišnje izvješće za 2019. godinu. 14 Hrvatska pošta d.d. (2018) Godišnje izvješće za 2018. godinu. 15 Hrvatska pošta d.d. (2019) Godišnje izvješće za 2019. godinu. 
Sopta, M.

Upravljanje digitalnom transformacijom državnog poduzeća poslovnice otvorene 24 sata, PAKETOMATI) i najvažnije inovacije kako bi unaprjeđivali postojeće poslovne procese i proizvode odnosno usluge $s$ ciljem snižavanja troškova. Najbolje se to vidi na primjeru pronalaženja novih niša u logističkom dijelu prilikom pojave COVID-19 krize koja je nužno postavila menadžment pred nove izazove $s$ kojima se uspješno nose. Ne treba zaboraviti i činjenicu da je Hrvatska pošta d.d. državno poduzeća što samim time znači ograničenja u upravljanju pa su rezultati poslovanja tog poduzeća time još i značajniji. Preporuke za daljnja istraživanja su da se analiziraju poslovanja drugih državnih poduzeća i u kojoj mjeri su njima pomogle inovacije u standardnom poslovanju odnosno na koji način su se usmjeravale nove razvojne strategije poslovanja.

\section{Literatura}

Cheung, S. N. S. (2020) The Contractual Nature of the Firm, Journal of Law and Economics, XXVI (1): 1-21, pretiskano Langois, R. N., Fu-Lai Yu, T., Robertson, P. (2002) Alternative Theories of the Firm, vol. I, Edward Elgar Publishing Limited, Cheltenham, Glos GL 50 i UA, UK, 245-265.

Coase R.(1937) The Nature of the Firm. Economica,4: 386-405. Ovaj članak je pretiskan u O.E. Williamson, S. E. Winter (ur.) (1993) The Nature of the Firm. Origins, Evolution, and Development. New York: Oxford University Press, 2: 18-33.

Copeland, T., Koller, T., Murrin, J. (1995) Valuation: Measuring and Managing the Value of Companies. New York: McKinsey \& Company, Inc.

Hrvatska pošta d.d. (2018) Godišnje izvješce za 2018. godinu.

Hrvatska pošta d.d. (2019) Godišnje izvješće za 2019. godinu.

Kamerschen, D. R. (1969) Readings in Microeconomics. Wiley.

Kuenne, R. E. (1966) Monopolistic Competition Theory: Studies in Impact. Essays in Honour of E. H. Chamberlin. Wiley.

Lazonick,W.(1992) Controlling the market for corporate control: the historical significance of managerial capitalism. Industrial and Corporate Change, 1(3): 445-488.

Mansfield, E. (1993) Managerial Economics: Theory, Applications, and Cases. New York: W. W. Norton \& Company.

Mansfield. E. (1998) Microeconomics. Theory and Applications. New York: W.W. Norton \& Company.

Marris, R. (1972) Is the corporate economy a corporate state? The American Economic Review, 62(1/2): 103-115.

Marris, R., Wood, A. (ur.) (1971) The Corporate economy: growth, competition, and innovative potential. Springer.

Orsag S. (2002) Budžetiranja kapitala: Procjena investicijskih projekata.Zagreb: Masmedia.

Santini I. (2001) Istraživanje mogućnosti primjene share-holder value u hrvatskim poduzećima. Magistarski rad, Ekonomski fakultet Zagreb.

Spence, A. M. (1975) The Economics of Internal Organization: An Introduction. The Bell Journal of Economics, 6(1): 163-172.doi:10.2307/3003219

Williamson, 0.E.(1975) Markets and hierarchies. New York, 2630: The Free Press.

Yamey, B. S. (ur.) (1973) Economics of Industrial Structure: Selected Readings. Harmondsworth, Middlesex, England: Penguin Books, Ltd., 233-262. 